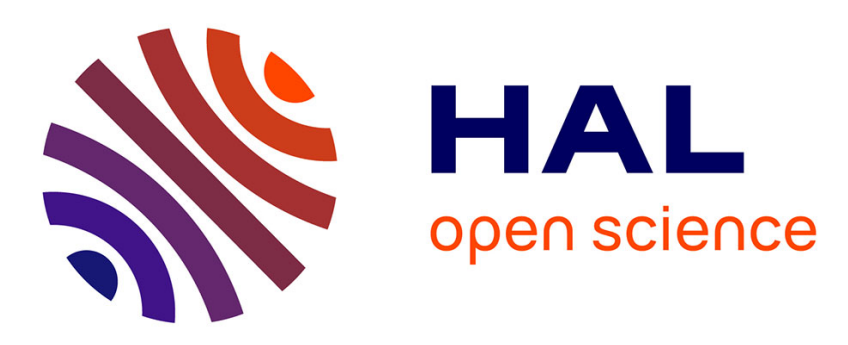

\title{
Spatial and territorial developments for life cycle assessment applied to urban mobility-case study on Lyon area in France
}

Cyrille François, Natacha Gondran, Jean-Pierre Nicolas

\section{To cite this version:}

Cyrille François, Natacha Gondran, Jean-Pierre Nicolas. Spatial and territorial developments for life cycle assessment applied to urban mobility-case study on Lyon area in France. International Journal of Life Cycle Assessment, 2021, 10.1007/s11367-020-01861-2 . emse-03119745

HAL Id: emse-03119745

https://hal-emse.ccsd.cnrs.fr/emse-03119745

Submitted on 22 Dec 2021

HAL is a multi-disciplinary open access archive for the deposit and dissemination of scientific research documents, whether they are published or not. The documents may come from teaching and research institutions in France or abroad, or from public or private research centers.
L'archive ouverte pluridisciplinaire HAL, est destinée au dépôt et à la diffusion de documents scientifiques de niveau recherche, publiés ou non, émanant des établissements d'enseignement et de recherche français ou étrangers, des laboratoires publics ou privés. 

mobility - case study on Lyon area in France

\author{
Cyrille François ${ }^{\mathrm{a}^{*}}$, Natacha Gondran ${ }^{\mathrm{b}}$, Jean-Pierre Nicolas ${ }^{\mathrm{c}}$ \\ aLaboratoire Ville Mobilité Transport, UMR T9403 ENPC-UGE, F-77455 Marne-la-Vallée, France \\ https://orcid.org/0000-0003-1311-6101 \\ ${ }^{b}$ Mines Saint-Etienne, Univ Lyon, Univ Jean Moulin, Univ Lumière, Univ Jean Monnet, ENTPE, INSA Lyon, \\ ENS Lyon, CNRS, UMR 5600 EVS, Institut Henri Fayol, F-42023 Saint-Etienne, France \\ https://orcid.org/0000-0003-0334-4303 \\ cLaboratoire Aménagement Économie Transports, ENTPE, F-69518 Vaulx-en-Velin, France \\ *Corresponding author: Laboratoire Ville Mobilité Transport, UMR T9403 ENPC-UGE, F-77455 Marne-la- \\ Vallée, France \\ E-mail address: cyrille.francois@enpc.fr
}

\begin{abstract}
Purpose The environmental assessment of urban mobility, defined as the movement of people in an urban area, exceeds the scope of transportation Life Cycle Assessment (LCA) with spatial, territorial and even social considerations. The objective of this study is to develop an original interdisciplinary method based on LCA coupled with a Land-Use and Transport Interaction (LUTI) model to better consider spatial and territorial dimensions in an environmental assessment of urban mobility.

Methods Spatial and territorial issues emerge in all LCA stages for urban mobility and this study illustrates them with an application on the Lyon urban area. To consider most individual daily trips, the geographical boundary is related to the area of influence of the city and the functional boundary includes all transportation modes, with motorized, public and non-motorized transports. The Life Cycle Inventories (LCIs) combined EcoInvent 3.2 inventories with a specific LUTI model, named SIMBAD, local mobility surveys and an emissions and consumptions model (COPERT5). These refinements allow a spatial environmental impacts assessment of urban mobility, expressed per inhabitant per day, at different residential locations and open opportunities to develop precise assessment methods for local air pollutants with detailed description on both population and pollution concentrations.
\end{abstract}

Results and discussion At territorial scale, this study highlights the major contribution to environmental impacts from private cars (around 90\%) and the relevance to consider fuel, vehicle and infrastructure life cycles in a mobility assessment. Spatial interpretations show important variability in function of residential locations and urban form characteristics related to different mobility behaviours, distance travelled and transport technologies used. Through the proposed assessment method for local air pollution impacts on human health, hotspots are revealed in the urban area, especially in the urban centre or along main road axes. In order to test our methodology and open discussions on mobility solutions, two contrasted scenarios are explored on compact city and vehicle electrification both presenting impact transfers between global indicators or with the air pollution exposure indicator.

Conclusions Urban mobility and its related environmental burden are not only related to technological choices but are also related to spatial characteristics and territorial context. The combination of urban and spatial tools and data, such as LUTI model, with the LCA methodology improves the local representativeness of environmental assessment of mobility and enlarges the ranges of analysis and perspective. Nonetheless, improvements remain to be made in relation to ongoing developments on Spatialized and Territorial LCA.

Keywords Urban mobility, Life Cycle Assessment (LCA), Land-Use and Transport Interaction model, Transportation, Territorial dimension, Spatial assessment 


\section{Introduction}

Strategic directions for environmental problem and greenhouse gas emissions mitigation were initially addressed by international forums (Earth Summits since 1972, Conferences Of Parties) (Brown Weiss 2011). The national and regional governments steadily enact laws (e.g. 2008 Climate Change Act in UK or Grenelle de l'Environnement in France in 2009) and strategic plans. However, a polycentric approach appears to be necessary to address global environmental issues (Ostrom 2009). Indeed, environmental concerns at local scale are omnipresent in debates and territorial projects. Agenda 21 plans, proposed during Rio de Janeiro Earth Summit 1992, emphasize territorial sustainable development and stakeholders' participation with the general principle “think globally, act locally" (UNCED 1992; Reed 2008). The term "Territory" generally refers to a geographical space based on an administrative boundary or on a natural or physical boundary. Nonetheless, it also embeds a social construction based on population and stakeholders space appropriation, making territories complex and dynamic systems (Moine 2006). Then, a territory appears as an appropriate area to raise concerns and implement projects, but also to establish local knowledge on environment with a necessity to integrate "think locally" and "think globally" in order to be able to implement relevant and coherent local actions.

Depending on territory's typologies (urbanization, location, wealth, culture), the contribution of daily mobility and its associated transport system on environmental damages varies (Newman and Kenworthy 1999; Kenworthy 2003). At every scale, from global to local, transport impacts on environment are significant. They represent, in 2018, 25\% of $\mathrm{CO}_{2}$ emissions at global scale (IEA 2019), and 27\% at European scale in 2017 (EEA 2018). In 2017, $29 \%$ of global final energy consumption and $65 \%$ of oil energy consumption (IEA 2019) was dedicated to transports. At local scale, transport is also blamed for environmental externalities. It contributes to air pollution and health damages in urban areas, around $23 \%$ of PM10 emissions in European cities with high variability along typologies and countries (Belis et al. 2013; Kumar et al. 2014). It represents the main source of noise pollution in Europe, with related health consequences (Hellmuth et al. 2012; EEA 2014). Many lands are occupied by roadways, especially in developed urban areas where up to $25 \%$ of built-up lands are roads (Servant 1996; Héran and Ravalet 2008). Territorial stakeholders are now under pressure to mitigate transports impacts in order to comply with regulations on climate, air quality or renewable energy development, to resolve health issues or to respond to citizen protests (e.g. climate March): they need to be able to deal with both global and local issues.

\section{Mobility and Urban System}

The concept of urban mobility represents the movement of people, or goods, in urban area and it is related to the socio-spatial organization of the urban society. It is central in a territory with the social and economic connections that it allows. The daily urban mobility of people can be defined as the whole movements linked to usual activities of people within the city and its space of influence. Then, daily urban mobility gathers both physical components of movements and social aspects associated to individuals and cities (Kaufmann et al. 2004). Mobility has a great impact on territories, it contributes to their economic development with the reduction of transport time and price and to their spatial organization with for instance the development of suburbs associated to car democratization (Dupuy 1999; Hoffman and Felkner 2002; Enault 2003). This connection is directly linked to the main role of mobility in urban systems, maintaining strong relations with others urban sub-systems (land-use, networks, housing and workplace development) (Wegener and Fürst 2004). Mostly considered as a social object, rather than technological one, urban mobility puts human in the centre of decision and analyses. Based on this social consideration, mobility solutions for sustainable development need to consider all ongoing dynamics influencing urban mobility in a territory: improvement or degradation of transport systems, urban planning, economic evolution, demographic evolution, behaviour changes, for example (Banister 2008). In that respect, transport system appears as an essential key for urban mobility, allowing and facilitating spatial relations, but it remains a support system for social and economic interactions.

Urban mobility is influenced by numerous and varied parameters, at different geographical scales. The main studied determinant is land-use, illustrated by the acknowledged relation between passenger car energy consumption and urban density (Newman and Kenworthy 1999). Since then, many research highlight the influence of global urban form, e.g. density, diversity, accessibility, (Cervero and Kockelman 1997; Schwanen et al. 2004; Naess 2012; Milakis et al. 2015) and local urban form, e.g. design, walkability, car parks, (Ewing and Cervero 2001, 2010; Banister 2008) on mobility. Cultural and socio-economic factors at territorial or individual scales also play a significant role on mobility through wealth, age, education, habits (Handy 1996; Ewing and Cervero 2001; Stead and Marshall 2001; Kenworthy 2003). Simultaneously, urban mobility evolution will affect the territory, its occupants and its dynamics (Stead and Marshall 2001; Marshall and Banister 2007). 


\section{Environmental Assessment of Transport System}

Mobility is also based on a transport system that represents all ways of transport (cars, public transport, bike, walking) and their associated infrastructure. Reciprocally, transport system adapts itself to mobility demand. For this reason, technological improvements of transports do not necessarily lead to reduction of transport environmental impacts if mobility demand still grows (also known as "the rebound effect") (Banister 2008). Nonetheless, most transport environmental assessments focus on transport systems or technologies rather than mobility. Different analytical tools have been used to assess environmental burdens of transport systems (e.g. onroad measures, laboratory measurement, fuel consumption based approaches, emissions and noises modelling) (André et al. 2006). Most assessments focus on use phase based on traffic flow estimation or counting with few impact categories assessed (Le Féon et al. 2012). The application of Life Cycle Assessment (LCA) in the transport sector may expand analysis horizons on its life-cycle with multicriteria approach.

LCA methodology is current in the transport sector for every component: car manufacturing (e.g. Bauer et al. 2015; Tagliaferri et al. 2016), fuel production (e.g. Hill 2013; Menten et al. 2013), transport infrastructure (e.g. Santos et al. 2017; Karlsson et al. 2017) or public transports (e.g. Del Pero et al. 2015; de Bortoli et al. 2017). Different scopes of analysis may be used to represent the transport system: cradle-to-grave scope covers the entire life cycle, cradle-to-gate concentrates on vehicle production, Well-to-Tank scope on fuel production, Tank-toWheel scope on fuel consumption and exhaust and Well-to-Wheel scope covers the fuel chain (Fig. 1) (Le Féon 2014).

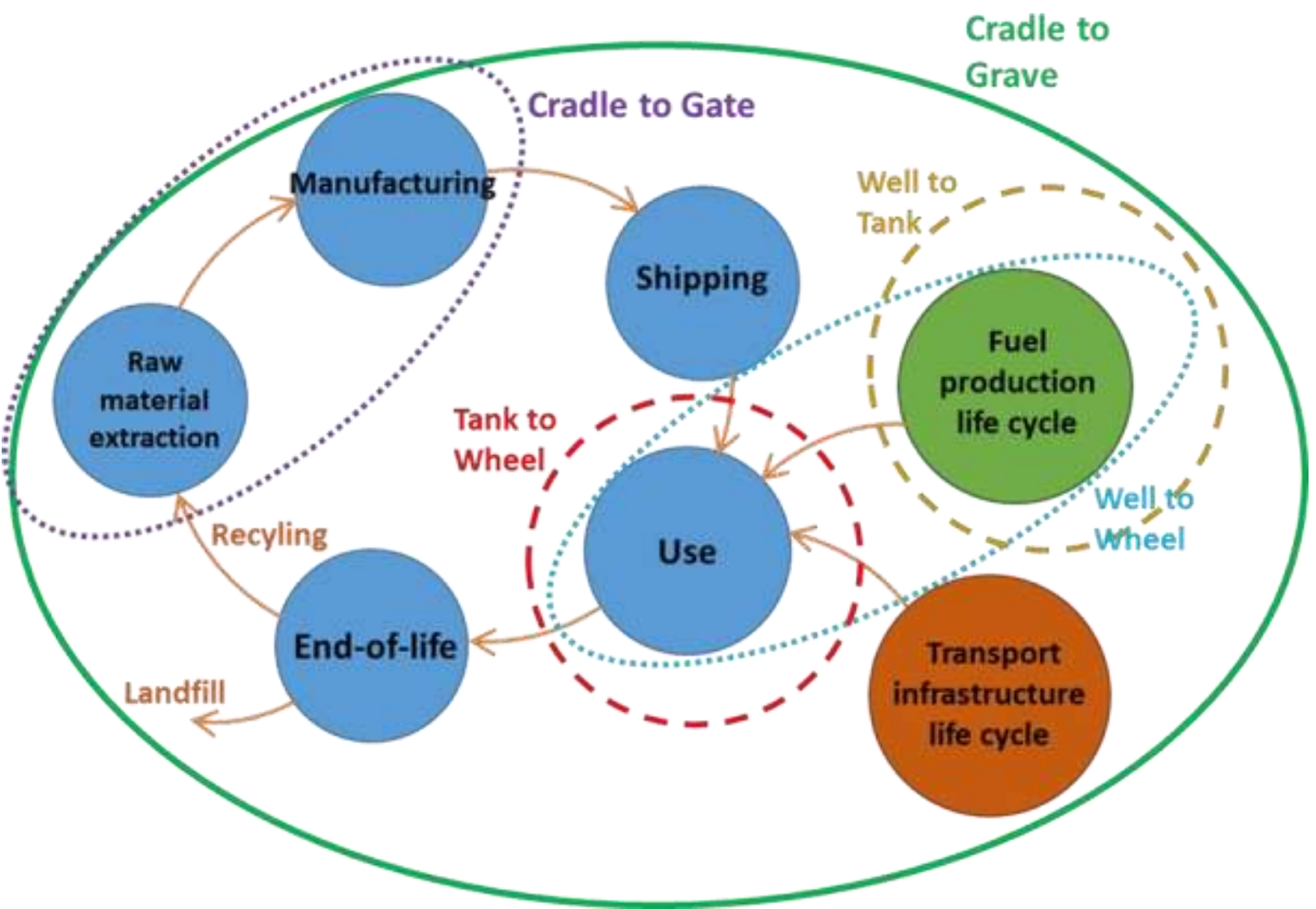

Fig. 1. LCA scopes descriptions for transport systems (Le Féon 2014)

For internal combustion vehicles, the operation phase represents the main source of GHG emissions and energy consumption, nonetheless other LC phases appear important with a multicriteria analysis (Chester and Horvath 2009; François et al. 2017). In recent years, knowledge on operation phase greatly develops with air quality regulation, car certification and tail pipes monitoring. Several consumption and emission models now exist to quantify car operation (e.g. COPERT (Ntziachristos et al. 2014), HBEFA (Eichlseder et al. 2009), PHEM (Luz and Hausberger 2010)) including car fleet composition (age, fuel, size) and driving conditions. The part of vehicle production and end-of-life in LCA grows in recent years with the electric vehicle development and the increase of vehicle weight (Del Duce et al. 2014; ICCT 2017). Many LCA studies analyse the fuel production impacts in regards to new motorization and biofuel development. Environmental impacts are significantly different between 
energies and some important impact transfers may occur from the operation phase to fuel production, e.g. electric cars or biofuels. However, fuel production impacts have significant spatial variability depending on extraction site, production technologies, transport, electricity production mix and biofuel incorporation rates (Ma et al. 2012; Eriksson and Ahlgren 2013; Menten et al. 2013). Transport infrastructures are less analysed in transport LCA, nonetheless their environmental impacts are substantial for specific transport system, especially for public transport (e.g. bus rapid transit (de Bortoli et al. 2017) or subways (Del Pero et al. 2015)), and even in the global transport system (Chester and Horvath 2009). Karlsson et al. also illustrate the influence of infrastructure choice location on the construction impacts by analysing the typology and soil characteristics (Karlsson et al. 2017).

LCA of mobility adds spatial and social variabilities to transport system analysis due to important fluctuations in population composition and distribution, mobility behaviours and transport modes accessibility. Comparative assessments carried on different urban areas highlight these variabilities based on surveys (e.g. Chester 2008; Le Féon 2014) or on modelization (e.g. Nichols and Kockelman 2014). Le Féon deepens the analysis by relating emissions to trip purposes and reveals the importance of an appropriate functional unit selection. He compared results by person.kilometer, such as most transport LCA, with results by inhabitant and he concluded on the major role of daily distance with difference up to $30 \%$ of kilometres travelled per inhabitant and per day between several French cities (Le Féon 2014).

\section{Spatialized and Territorial LCA}

LCA has been initially developed as an aspatial assessment method with a global approach based on the assumption of spatial and temporal homogeneity of the environment (Jolliet et al. 2016). Nonetheless this assumption can be a potential source of errors especially in regards to spatial distribution of sources, fate factors, exposure factors and effect factors (Potting and Hauschild 1997; Finnveden et al. 2009). This observation led to the development of Spatialized LCA in the recent years. And more recently researchers propose new methods for the environmental assessment of a territory with LC thinking, Territorial LCA (Nitschelm et al. 2016; Loiseau et al. 2018).

Spatial differentiation in LCA may reduce misconclusions from studies especially through the implementation of site-specific and site-dependant approaches (Hellweg and Mila i Canals 2014). All stages of LCA methodology can include spatial and geographical aspects (Aissani 2008) with respect of study objectives, uncertainty tolerance, geographical data availability and human resources (Baitz et al. 2013; Patouillard et al. 2016). At the goal and scope stage, the definition of the studied system and its boundary may imply spatial investigation, especially in case of a multifunctional system where spatial context influences the functions relevance (Laurent 2015). During the LCI construction, spatial information can be used to improve representativity through contextualized data or regionalized databases (Wernet et al. 2016). With Geographical Information System (GIS), spatial information can be attached to processes and their associated elementary flows to quantify them and to connect them with corresponding receiving environment (Liu et al. 2014; Karlsson et al. 2017; García-Pérez et al. 2018). Spatial differentiation in LCIA aims to distinguish characterization factors (CFs) in regards of impact categories and the spatial variation of the receiving environment and its sensitivity (Potting and Hauschild 1997). Most spatialized LCIA detailed CFs at countries or watersheds levels for regional impacts: acidification (Potting et al. 1998), eutrophication (Huijbregts et al. 2000), water scarcity (Boulay et al. 2018). The characterization method IMPACT World+ goes further by calculating CFs at different levels of geographical resolution (global, continental, countries or native regions) for all regionalized impacts (Bulle et al. 2019). For interpretation, spatial information can be used for results mapping and addressing potential spatial heterogeneity of impacts and potential geographical transfers.

Territorial LCA evaluates the environmental burden of a territory, and all related human activities. Very few Territorial LCA studies include all types of activities (Loiseau et al. 2013), most focus on specific sectors: agriculture, energy, water, waste, transport (Nitschelm et al. 2016; Mirabella et al. 2018). The territorial and urban context influences all stages of LCA, especially goal and scope definition with several issues. After the goal definition, the functional unit(s) of the selected system needs to be specified in regards to the multifunctionality associated to territories (Pérez-Soba et al. 2008). Then, geographical boundaries should be set depending on the goals and the stakeholders involved. For urban territory, boundaries could be based on administrative concerns (administrative-based boundaries). This facilitates data collection and is more relevant in terms of decision-support related to local competences. However, these administrative boundaries may omit some important population and services located outside of the administrative area, but influencing it. Density-based boundaries are built on urban form continuity to better enclose services and population influenced by urban centre. Nonetheless, some other regional services might be excluded, such as economic, logistic or touristic services. The extension of geographical 
boundaries to all services (service-based boundaries) raises an allocation issue between territories sharing services (e.g. airport, industrial parks) (Albertí et al. 2019). Once Boundaries are fixed, activities are differentiated between foreground (on-site) activities that occur inside the territory's perimeter and the background (off-site) activities induced by foreground activities and all territorial consumption (Azapagic et al. 2007; Loiseau et al. 2013). This differentiation will be used in data collection process, on the one hand, foreground activities are directly influenced by territorial decision and related data should have good representativity with potential georeferencing (O'Keeffe et al. 2016). On the other hand, territory has no influence on background activities that could be represented by average values. Territorial and local contexts can be used for LCIA to qualify the receiving environment and to implement specific CFs. Territorial LCA appears appropriated to establish the environmental footprint of a territory considering both its activities and its relations with other territories (Nitschelm et al. 2016).

Territorial LCA method might be partly based on Spatialized LCA methods. Nitschelm et al. propose a combined method for agricultural activities, the Spatialized and Territorial LCA, that emphasizes on the boundaries and functions definition, the localization and characterization of activities and environment typologies, the spatialization of emissions, the LCIA and the mapping of in-site and off-site impacts (Nitschelm et al. 2016).

The objective of this article is therefore to contribute to methodological development on spatialized LCA and urban assessment through an application for urban mobility. This contribution focuses on the capabilities of transport management and urban planning tools to overcome potential difficulties related to spatialized and territorial LCA. The interdisciplinary method developed for the urban mobility gathers socio-spatial knowledge from land-use planning and technological and environmental information from engineering sciences to improve the spatial and territorial representativeness in a LCA.

\section{Methods}

\subsection{Spatial and territorial considerations for urban mobility}

Regardless of the scale and size of territories, spatialization is central in mobility debates and it occurs at all four stages of a LCA: goal and scope, inventory, impacts assessment and interpretation (Aissani 2008).

In goal and scope definition the main spatial debate is on the geographical boundary. The length of daily trips is increasing with the improvement of transport technologies' efficiency and speed (Zahavi and Ryan 1980; Schafer and Victor 2000) making difficult to set geographical limits especially at city and metropolis levels where metropolization process needs to be integrated (Wiel 1999).

The relevance of spatialized and territorial LCI arises from two points. First the traffic conditions have a great impact on emissions and consumption of the transport system (Smit 2006). Secondly, the implementation of local mobility policies influences the emissions and consumption factors and the kinds of transport technologies used, for example Low-Emission-Zone (André et al. 2018), car-pooling lanes (Shaheen et al. 2016) or electric vehicles incentives (Querini and Benetto 2015).

During LCIA, attention on spatialized characterization factors that take into account the densities of both pollutants and population is high especially in urban area. For daily urban mobility the impacts of air pollutants on human health is an important concern from regional to neighbourhoods' scales. The exposure factor, crossing air pollution level with population density, is highly variable in space and cannot be represented by generic value (Krewitt et al. 2001).

At the interpretation stage, the spatialization mainly focuses on maps representation to identify hotspots on emissions and impacts. In mobility assessment, the spatialization of results is an important step to interpret environmental and territorial equity with potential transfers between territories. Different approaches can be used to represent the emissions that are generated by, and on, a territory: the cadastral approach, which is often used in territorial GHG diagnostic, aims at mapping direct emissions, in spatial units (e.g. Cortinovis et al. 2006), or the footprint approach (environmental, carbon or water), that can also be spatially addressed through the assessment and the mapping of environmental burdens that are generated by the consumptions of households that are located in the spatial units of a territory (Minx et al. 2013; Ivanova et al. 2017). Spatialized environmental footprint of households has been studied in Swiss context including residential, mobility and food consumption burdens (Saner 
et al. 2016). Then the environmental assessment of urban mobility required an important level of spatialization at all stages of LCA, from boundary definition to impacts and contributors mapping, and territorial considerations. The current study covers some spatialized and territorial aspects of the LCA framework at each of LCA stages: (1) goal and scope definition, (2) LCI, (3) LCIA and (4) interpretation (Table 1). The main particularity of the developed method is the coupling of a LCA with an urban model based on Land-Use and Transport Interaction, a LUTI model. In addition, the interpretation stage offers three original dimensions of analyses: (1) mobility behaviours and stakeholders analyses with trip purposes and households' discretization in regards to territory's boundary, (2) spatial analyses at spatial units of household's contributions and (3) local emissions and exposure analyses at fine scale to represent potential health damages as illustrated in Fig. 2. Then the proposed analysis framework covers main technological, spatial and social dimensions associated to daily urban mobility.

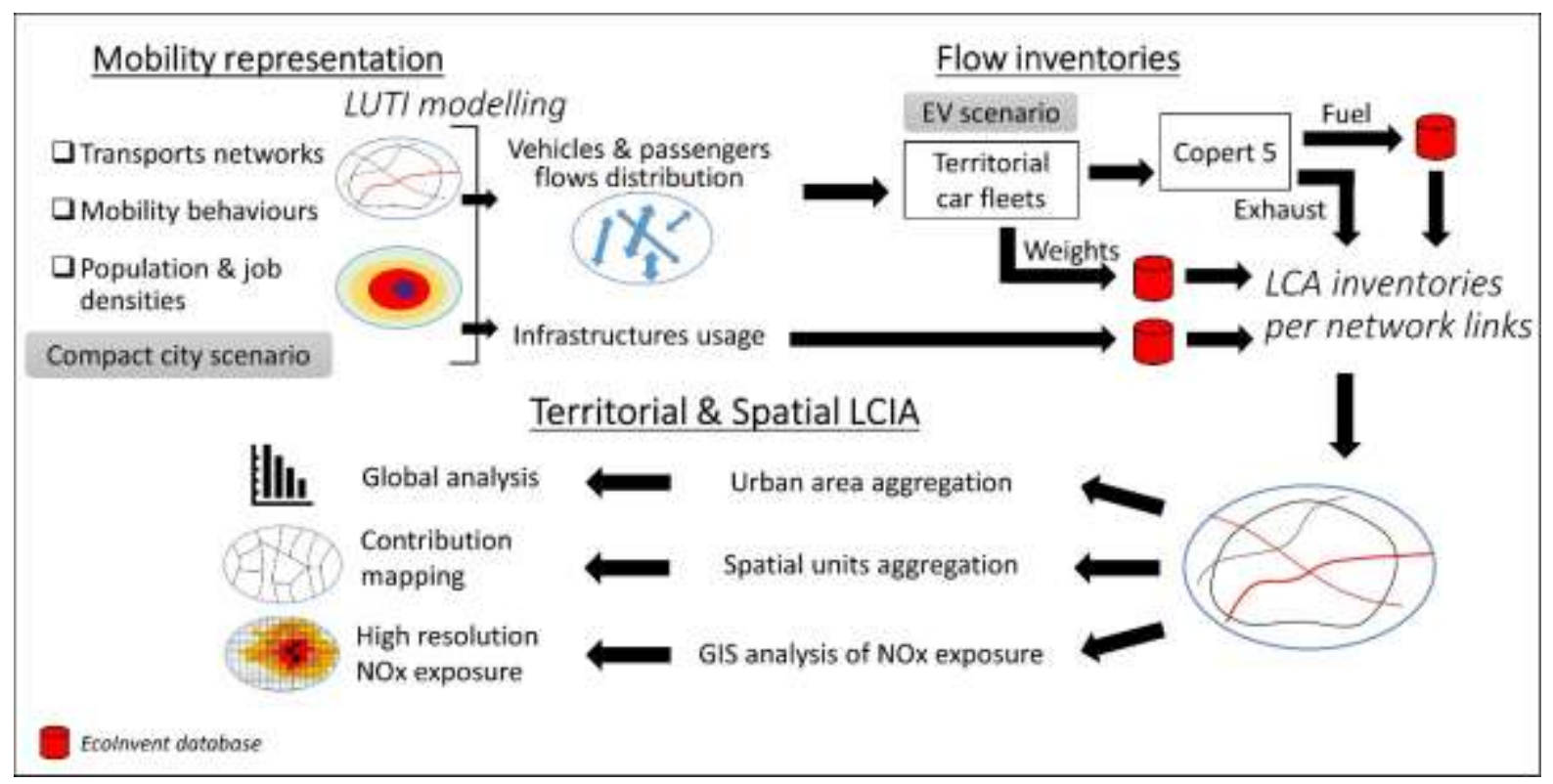

Fig. 2. Diagram for methodological framework applied for urban mobility LCA

\section{Table 1}

Territorial and spatial considerations for urban mobility

Territorial and spatial considerations for urban mobility

\begin{tabular}{cc}
\hline LCA steps & Main territorial and spatial issues \\
\hline Goal and scope & - \\
\hline Goal & $\begin{array}{l}\text { Depending on territorial urban } \\
\text { planners and stakeholders }\end{array}$
\end{tabular}

System

- Two approaches: related to a specific activity or all activities within the territory Implementation for urban mobility

- From cradle-to-territorial gate, gate-to-grave, cradle-to-grave

- Depending on production or consumption issues

Functions

Functional unit

- Multifunctionality

- Spatial variability of functions

- Embodied territorial functions and context

- Remains comparable
- Reflective tool for territorial stakeholders from regional to local scale

- Transport system supporting the daily urban mobility of people

- From cradle-to-grave in regards to the consumption issues of transports, incl. vehicles, fuels and transport infrastructures

- Functions of mobility related to trip purposes (work, shopping, leisure, school ...)

- Per person per day, in regards of their daily activities schedules 
- Administrative-based, density based or service based boundaries

- Dynamic boundary
- Urban area boundary, defined on daily commuting 
Life Crcle

Inventorv - LCI - Regional data collection

- Geolocated processes

Impacts

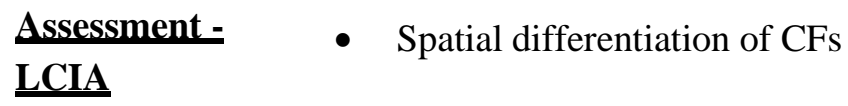

Interpretation

Scenarios

- According territorial context and stakeholders visions

Spatial analysis - Mapping impacts

- In-site and off-site distinction
- Uses of vehicles spatially and temporally modelled

- Territorial vehicles fleets

- First approach without spatialized LCIA

- SIG development for human toxicity

- Wide range of scenarios to address different visions (urban planning, technologies, network or mobility behaviour)

- Impacts and contributors mapping

- In-site and off-site distinction

\subsection{Goal and scope \\ 2.2.1. Goal}

As few LCA studies exist on urban mobility, the goal of the study is to firstly develop and test an original methodology coupling on urban model and LCA. Beyond the research aspect, the method aims to inform and advise all stakeholders involved in transport and mobility policies from local (e.g. parking regulation) to regional (e.g. interurban train systems) through a reflective tool rather than a decision-support tool. In regards to this goal, spatial and territorial issues of an existent situation will be assessed with a prospective approach based on scenarios.

\subsubsection{System}

In a complete territorial LCA, all activities occurring within the territory should be represented (Loiseau et al. 2018), nonetheless most territorial studies focus on specific sectors. The present study focuses on the passenger transport and mobility ones. The mobility system chosen represents all trips generated by every residents of the territory for their daily activities, meaning activities during an average business day. This system definition removes all occasional holidays and weekend trips and the freight transport related to the territory.

\subsubsection{System boundaries}

By reducing the system to the territory's daily mobility of persons, the amount of data needed is reduced to these daily trips and to represent the related technologies, all long-distance and freight technologies are not included. As a consequence, the system under study includes personal transport, motorized and non-motorized, and urban public transports by bus and rail transport. The scope considered extends from the cradle to the grave including vehicles use, their manufacturing and end-of-life, all fuel production (traditional fuels, biofuels and electricity) and transport infrastructure life cycle. The suggestion to stop the scope at the territory gate has not been selected to get a complete picture of transports' environmental burden, in particular in view of trying to better represent the environmental impacts of electric mobility.

\subsubsection{Functions}

The functions definition is a crucial step in LCA, especially for territorial object such as daily mobility since territory is a multifunctional object itself. As daily mobility is related to all activities that may take place on a geographical area, its functions will embrace all categories of available activities, depending on territory demography, wealth, quality of life, culture. These activities categories refer in mobility studies at trip purposes: work, shopping, education, leisure, visits and others. At the territorial scale, daily mobility can be considered by stakeholders as both a driver for economic and social development or a support of territorial functions. 
In our study, daily mobility was considered as a support function for trips of residents of a territory. The function under study was then "Meet the demand for travel by people in the urban system of an urban area during an average working day" (François 2019).

\subsubsection{Functional unit}

The associated functional unit chosen was "to meet the demand for travel per inhabitant per day" allowing discretizations by inhabitants' characteristics. In comparison with the passenger-kilometre unit, mostly used in transport assessment, the chosen unit embedded the daily distance travelled. This approach, restricted to the material aspects of the daily mobility of persons, was not intended to represent mobility as a driving force for economic and social development.

\subsubsection{Territorial boundary}

The geographical boundary definition for urban mobility is complex because it goes way beyond the administrative boundaries of the city and the influence area of the city is extending with ongoing urban expansion. To better represent the spatial influence of urban mobility, the French statistics bureau (INSEE) defined the urban area based as a work catchment area of an urban conurbation. In 2017, France has 81 urban areas with up to 100,000 inhabitants.

\subsection{Mobility representation}

To represent this urban system and its associated mobility, urban and transport model have been developed worldwide mainly at decision-support purposes (Marshall and Banister 2007). Land-Use Transport Interaction (LUTI) models offer a systemic approach of mobility by representing diverse urban relationships especially the Land-Use Transport interrelations (Wegener and Fürst 2004). From the spatial distribution of activities and population on the territory and its associated transport networks, a LUTI model estimates the flow distribution of trips and their potential consequences on land-use. An important variety of LUTI models exists, representing different urban systems and answering different issues. Beside the theoretical basis of models, the main differentiations are on the spatial coverage (from neighbourhood to regions), spatial resolution (from agent-based modelling to macro zones) and dynamic aspects (static or dynamic models) (Hunt et al. 2005; Wilson 2010; Jones 2016). Despite the assets of LUTI modelling, dissensions remain between scientific rigour and operationality in regards to needed resources for development (Saujot et al. 2015).

\subsection{Life Cycle Inventory - LCI}

Data collection and inventory are differentiated between foreground and background activities in regards to their specification for the system. The data collection on vehicles use (distance, occupancy, speed) and infrastructure's use is estimated by a LUTI model developed on a specific urban area. In addition of networks and flows data, LUTI models may provide socio-economic information on inhabitants. The environmental inventory is then calculated through an emissions model and the EcoInvent database for respectively direct and indirect emissions and consumption, as presented in François et al. (2017).

\subsubsection{Foreground activities: vehicles use}

LUTI models do not provide information on the technologies used and pollutants emitted on each link. Nonetheless, foreground activities need an appropriate level of detail with spatialization and local process specification. Territorial details on fleet composition allows specification on consumption and emissions factors. Depending on personal car data availability, distinct vehicles fleets are estimated for diverse population groups. These fleets descriptions are described more precisely, as well as other LCI data description, in (François 2019). They allow the conversion of vehicles flows into vehicle technology use in regards to engine motorization, vehicles size, Euro norms and potential depolluting technology. Similar fleet description is realized for the urban bus fleet based on the operator's data.

The estimation of emissions and fuel consumption of vehicles on the network is made by the model COPERT 5 (Ntziachristos et al. 2016). By integrating most vehicles' specifications (fuel, size, age, depolluting systems) and the average speed related to different types of driving conditions, COPERT 5 offers a high level of description for all exhaust (warm and cold engine) and abrasion (from brakes, tyres and road) emissions and all fuel consumption (incl. AC overconsumption). Then the coupling of LUTI outputs, car fleets statistics and COPERT 5 model offers one of the best environmental representation with spatial distribution on links and contextualization with local vehicles' technologies and local speed condition. 


\subsubsection{Background activities}

Based on LUTI data, car fleets descriptions and consumption model, all, or most, quantities of background processes are accurately estimated, e.g. quantity of fuels, travel's total length for each vehicle type, length of each infrastructure type. Most background activities locations are unknown and are related to processes description provided by EcoInvent 3.2 database (Wernet et al. 2016). Nonetheless, few modifications were made to better represent all the range of vehicles and the different types of roads and infrastructure involved for the daily mobility in an urban area, especially for rail public transports.

\subsection{Impacts Assessment - LCIA}

Spatialized and territorial LCIA required respectively the implementation of spatialized characterization factors and the consideration of the local context while evaluating impacts. In this study, efforts have been focused on vehicles use spatialization rather than environmental characterization.

\subsubsection{Aspatial assessment}

The selected impact assessment methods, that were used, do not consider spatial differentiation nor territorial specification (Table 2). Nonetheless, the seven midpoint indicators that were chosen in this method were selected through the interviews of fifteen territorial stakeholders' interviews. It appears that the most relevant indicators to follow: climate change potential, particulate matter formation, photochemical ozone formation, terrestrial acidification, metal depletion, land use and primary energy demand. Other indicators appeared less relevant for transport systems in urban context for local stakeholders. For each impact category, the selection of the impact assessment method has been guided by the ILCD recommendations with respect of available data (Table 2).

Table 2

Selected impact categories, associated methods, units and abbreviations

\begin{tabular}{|c|c|c|c|}
\hline Impact category & method & unit & Abbr. \\
\hline Climate change & ReCiPe/IPCC 2013 (GWP100) & $\mathrm{kg} \mathrm{CO}_{2}$-eq & GWP \\
\hline Particulate matter & ILCD $2011^{\mathrm{a}}$ & $\mathrm{g} \mathrm{PM}_{2.5}$-eq & PMF \\
\hline Photochemical ozone & $\mathrm{ReCiPe}^{\mathrm{b}}$ & g NMVOC-eq & POF \\
\hline Terrestrial acidification & $\mathrm{ReCiPe}^{\mathrm{b}}$ & $\mathrm{g} \mathrm{SO}_{2}$-eq & TAP \\
\hline Metal depletion & $\mathrm{ReCiPe}^{\mathrm{b}}$ & g Fe-eq & Metal \\
\hline Land use & $\mathrm{ReCiPe}^{\mathrm{b}}$ & $\mathrm{m}^{2}$.an & LandUse \\
\hline Primary energy & Cumulative Energy Demand ${ }^{c}$ & $\mathrm{kWh}$ & CED \\
\hline
\end{tabular}

${ }^{a}$ European Commission/Joint Research Centre, 2011

${ }^{\mathrm{b}}$ Goedkoop et al., 2009

${ }^{\mathrm{c}}$ Hischier et al., 2010

\subsubsection{GIS based assessment for air pollutants impacts on human health}

The high concern of urban stakeholders for air quality and human health leads us to develop a spatialized LCIA method for local pollutants. The proposed method is based on GIS data processed at a small square level $(250 \mathrm{~m} \times 250 \mathrm{~m})$ to highlight specific potential hotspots for human health damage associated to air pollution generated by daily mobility. For each square, an exposure factor was approximated by the residential population density level, which was estimated based on built-up and population information obtained through the LUTI model excluding the presence of workers or other visitors. The intake factor was approximated by the daily quantity of pollutants emitted by all links in each square. This approach ignores air pollutants transport and dispersion as well as air pollutants that are generated by other sources than the transports of persons. Thus, it endeavours to present a first and rapid overview of the zones that are potentially exposed to air pollution. It cannot substitute a deeper assessment and analyse of urban air quality. In this article, only NOx emissions are considered to facilitate both calculation and interpretation.

The human health damage level is estimated by crossing population density levels and emissions density levels, both in quintiles (Fig. 5). Human health damage indicator associated to the emissions of air pollutants by the daily mobility, varies on each square from zero, if no population or no emission are present, to six, in case of higher densities of the population and the emissions simultaneously. This high spatial resolution allows map representation and accurate analysis for different territories, e.g. the city centre.

\subsection{Interpretation}

Following the goal of this study, to develop a reflective tool for diverse territorial stakeholders, the associated analysis framework is going to be broad enough to cover main spatial and territorial issues related to environmental impacts of daily mobility. Three general points can be explored, the on-site and off-site impacts transfers, the 
heterogeneous distribution of emissions and contributors inside the territory and the prospective and sensitivity analysis.

\subsubsection{In-site and off-site analysis}

The geographical boundary definition distinguishes foreground and background activities. For a vast territory such as an urban area, in-site activities refer to vehicles operation emissions from vehicles use. Vehicle, fuel and infrastructure productions are considered to be located outside the territory, even if car-manufacturers, refineries or asphalt plants might be established on the territory. However, this spatial differentiation matches with a temporal differentiation because an important gap exists between vehicles operation emissions occurring on a daily basis and vehicle and infrastructure productions appearing years, even decades, earlier.

\subsubsection{Contributors mapping}

Due to the heterogeneous spatial distribution of population, activities, means of transport, transport technologies and behaviours, the environmental contribution of each inhabitant varies significantly inside the territory. To assess this spatial distribution, all possible connections between all spatial units were assessed by adding composing links. Then, environmental impacts were calculated for each spatial unit by retracing all trips simulated by LUTI models. This disaggregation allows two interpretations, one with an emitter point of view, considering emissions at residential areas, and another one with a generator's point of view considering emissions at areas of activity. In both cases, environmental indicators can be mapped and correlated with urban characteristics (density, functional mixing and accessibility).

\subsubsection{Scenarios approach}

To perform a sensitivity analysis in LCA, each parameter should be evaluated separately to assess his sensitivity. Nonetheless, in case of territorial LCA, parameters are too numerous to execute a complete sensitivity analysis. The scenarios approach is another way to test sensitivity of systems by exploring diverse prospective visions. Based on the proposed method a wild range of sensitivity and prospective visions can be implemented and analysed: urban planning scenarios, economic and demographic evolutions, new mobility behaviours scenarios, transports networks scenarios, fleets evolutions or fuels productions (François 2019).

\subsection{Case study}

Our case study assesses the mobility of the second urban area of France, Lyon with up 2,300,000 inhabitants in 2017 composed of nearly 500 municipalities and crossing distinct administrative divisions. Lyon has the geographical specification to be a monocentric urban area with mostly radial trips and a high central density (up to 10000 inhabitants per $\mathrm{km}^{2}$ for Lyon City). The Lyon public transport system is well developed and diversified with bus, trolleybus, train, tramway and subway lines (Supplementary doc).

The LUTI model, SIMBAD, was developed by the Laboratoire Aménagement Économie Transport (LAET) on this urban area and it was initially designed to estimate sustainability of alternative policies in urban and transport planning (Nicolas et al. 2009). Based on an iterative loop, SIMBAD considers initial locations of activities and residents in the territory in order to estimate the mobility through a four steps transport model: (1) trips generation, (2) spatial distribution, (3) modal share and (4) network affectation. Then, accessibility levels of each spatial unit are calculated and then activities and residents might relocate by using a land-use model. Baseline mobility characteristics are displayed in Table 3.

The model provides certain outputs for the LCI. Firstly, it describes the entire network for both road vehicles and rail public transport, with detail on each link (length, road category, average speed, public transport lines and frequencies). Secondly, the SIMBAD model calculates on each link the flows of passengers and vehicles in regards to nine different inhabitants' categories based on income and location (centre, inner-suburbs and outer-suburbs) for peak and off-peak hours. Based on local mobility survey in 2015, each nine inhabitants' categories personal car fleet was estimated to describe vehicles characteristics (Supplementary doc).

In this article, two contrasted scenarios are explored and analysed all things being equal: (1) the compact city scenario, where $10 \%$ of the outer-suburb housing and activities are relocated in the central area, the new mobility organization is presented Table 3; (2) the electric vehicles scenario, where a significant part of the personal car fleet is electrically powered, depending on inhabitants' income and location (considering the 2012 French national electrical mix) (Supplementary doc). 
Table 3

Modal splits and travelled distances of simulated mobility

\begin{tabular}{lccc}
$\begin{array}{l}\text { Per inhabitant } \\
\text { per day }\end{array}$ & Baseline & $\begin{array}{c}\text { Compact city } \\
\text { scenario }\end{array}$ & $\begin{array}{c}\text { Electric vehicles } \\
\text { scenario }\end{array}$ \\
\hline \multicolumn{1}{c}{ Nb of trips } & 2.72 & 2.78 & 2.72 \\
$\% P V$ & $60 \%$ & $56 \%$ & $60 \%$ \\
$\% P T$ & $16 \%$ & $18 \%$ & $16 \%$ \\
$\%$ soft modes & $24 \%$ & $26 \%$ & $24 \%$ \\
Distance travelled & $16.2 \mathrm{~km}$ & $14.7 \mathrm{~km}$ & $16.2 \mathrm{~km}$ \\
Personal vehicle & $12.9 \mathrm{~km}$ & $11.3 \mathrm{~km}$ & $12.9 \mathrm{~km}$ \\
Public transport & $2.2 \mathrm{~km}$ & $2.3 \mathrm{~km}$ & $2.2 \mathrm{~km}$ \\
Soft modes & $1.1 \mathrm{~km}$ & $1.1 \mathrm{~km}$ & $1.1 \mathrm{~km}$ \\
PV occupancy rate & 1.26 & 1.26 & 1.26 \\
Passengers per car & & & \\
\hline Resur
\end{tabular}

\section{Results}

The environmental impacts of daily mobility of Lyon urban area inhabitants, expressed per inhabitant per day, and life cycle contributors are presented in Fig. 3. Public transports produced noticeable impacts with between $8 \%$ to $15 \%$ of total environmental impacts. Use phase (incl. exhaust and abrasion) does not appear as a predominant contributor on environmental impacts with a maximum contribution of 55\% for GWP. In our case, only vehicle operation emissions are considered on-site, then off-site processes emerge as significant reflecting the dependency of this territorial mobility for abroad processes with impacts relocation. The daily mobility carbon budget for Lyon urban citizens is estimated at $3.22 \mathrm{~kg} \mathrm{CO}_{2}$-eq being consistent with previous study made on others French cities (Le Féon 2014). The energy breakdown highlights the low share of renewable energy in the urban transport system and the relevant nuclear energy consumption in infrastructure processes and public transport fuel.

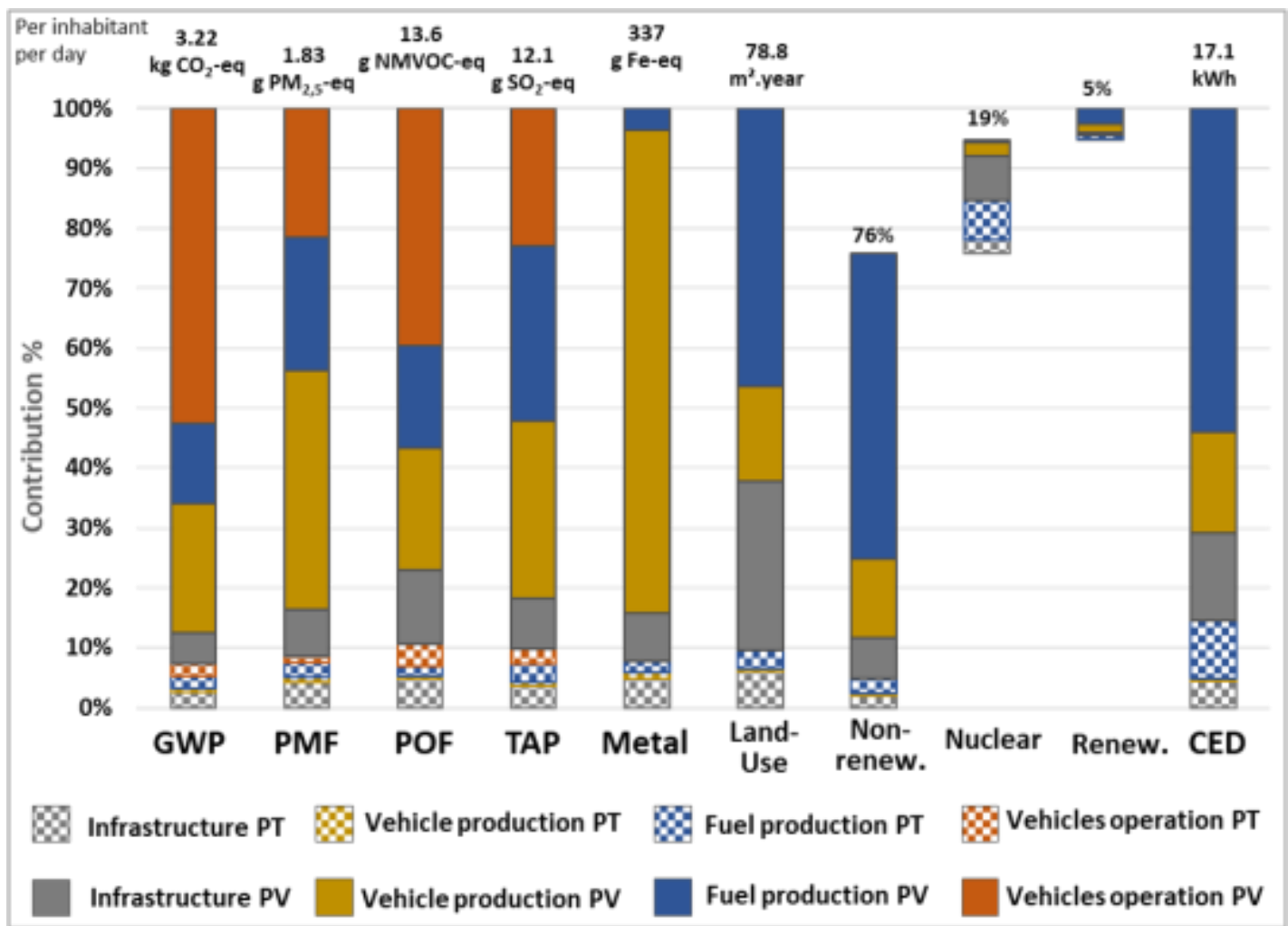

Fig. 3. Life cycle stages contributions to impact categories for daily mobility (PT: Public Transport, PV: Personal Vehicle)

GWP: Climate change; PMF: Particulate matter; POF: Photochemical ozone;

TAP: Terrestrial acidification; CED: Cumulative energy demand

The main impacts of urban mobility scenarios are presented in Table 4. The compact city scenario generates less environmental impacts than the original urban organization for all LCA indicators. Compact urban form reduces 
environmental burdens due to the promotion of active modes and public transport and the reduction of travelled distance. Nonetheless, effect is not linear with side effects such as congestion and gentrification mechanisms. The electric vehicle scenario leads to some transfers of impacts from air pollution to metal depletion and it does not reduce total energy consumption. Impact transfer also occurs from on-site processes to off-site processes with electricity production and vehicle production and end-of-life gaining prominence.

\section{Table 4}

Comparison of the main environmental burden in three mobility scenarios

\begin{tabular}{|c|c|c|c|c|c|}
\hline Scenarios & $\begin{array}{l}\mathrm{GWP} \\
\mathrm{kgCO}-e q\end{array}$ & $\begin{array}{l}\text { PMF } \\
g P M_{2.5}\end{array}$ & $\begin{array}{l}\text { CED } \\
k W h\end{array}$ & $\begin{array}{l}\text { Metal } \\
g \text { Fe-eq }\end{array}$ & $\begin{array}{l}\text { NOx exposure } \\
\text { score }\end{array}$ \\
\hline Baseline & 3.22 & 1.83 & 17.1 & 337 & 2.35 \\
\hline Compact city & $2.94(-8.7 \%)$ & $1.68(-8.2 \%)$ & $15.9(-7 \%)$ & $307(-8.9 \%)$ & $2.57(+9.4 \%)$ \\
\hline Electric vehicles & $2.79(-13.3 \%)$ & $1.65(-9.8 \%)$ & $17.1(0 \%)$ & $459(+36 \%)$ & $2.18(-7.2 \%)$ \\
\hline
\end{tabular}

Our complete transport system effectiveness, expressed per passenger-kilometre, is estimated for GWP at $202 \mathrm{~g}$ $\mathrm{CO}_{2}$-eq per pkm, above other French mobility study estimation and below American metropolis transports assessment (Chester et al. 2010; Le Féon et al. 2012). Our studied object, assessed per inhabitant per day, bring multifunctionality that can be related to trip purposes. The Fig. 4 represents distributions of total home leavings, distance and GHG emissions for the six main purposes. Travelled distance and modal share vary with the trip purposes, making commuting trips the main contributors of total mobility environmental impacts. Then, at territory or household scales, the employment ratio influences significantly the environmental performance of the related daily mobility. For example, the GHG emissions per inhabitant per day are 3.5 times higher in a dual-career couple than an unemployed person, which lives alone.

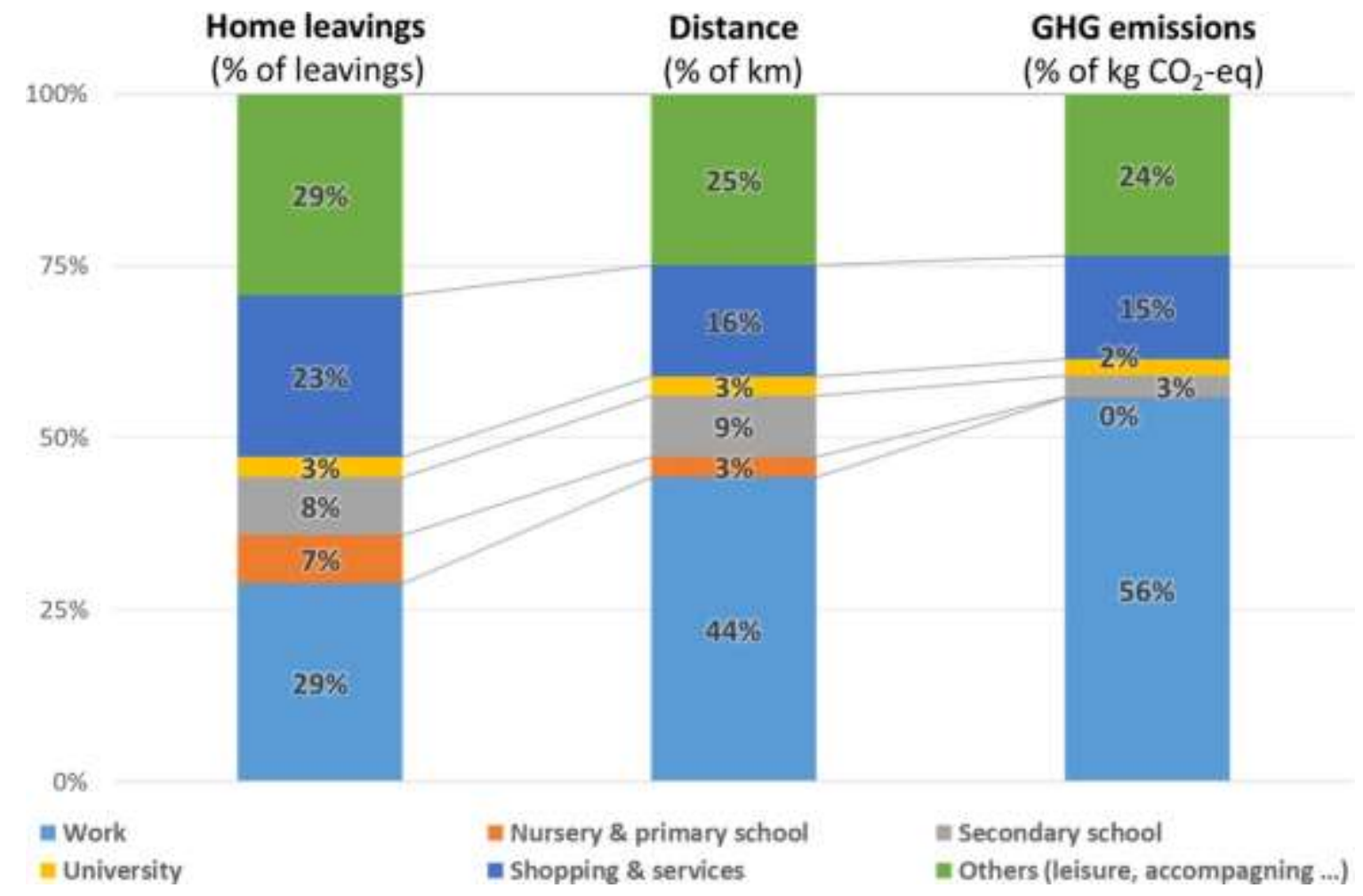

Fig. 4. Home leavings, travelled distance and GHG emissions distribution between main trip purposes

Spatial distribution of emitters

The spatial distribution of GHG emissions levels associated with inhabitants in each residential area is presented in the Fig. 5. Similar distribution is obtained for other environmental indicators. People living in central areas produce individually less impacts, for their daily mobility, than other inhabitants of the Lyon urban area. Only $8 \%$ of the total surface presents a GHG emission level below the urban area mean, $3.2 \mathrm{~kg} \mathrm{CO}_{2}$-eq. In terms of contributions, the city centre generates $17 \%$ of total daily mobility GHG emissions but it hosts $37 \%$ of the population. In comparison, the outer-suburb, located outside the administrative metropolis, generates $45 \%$ of GWP 
impacts but with $27 \%$ of the population living. In this peripheral area, the higher environmental burden is caused by the dominant use of individual cars, the modal share exceeds $80 \%$ in most residential areas.

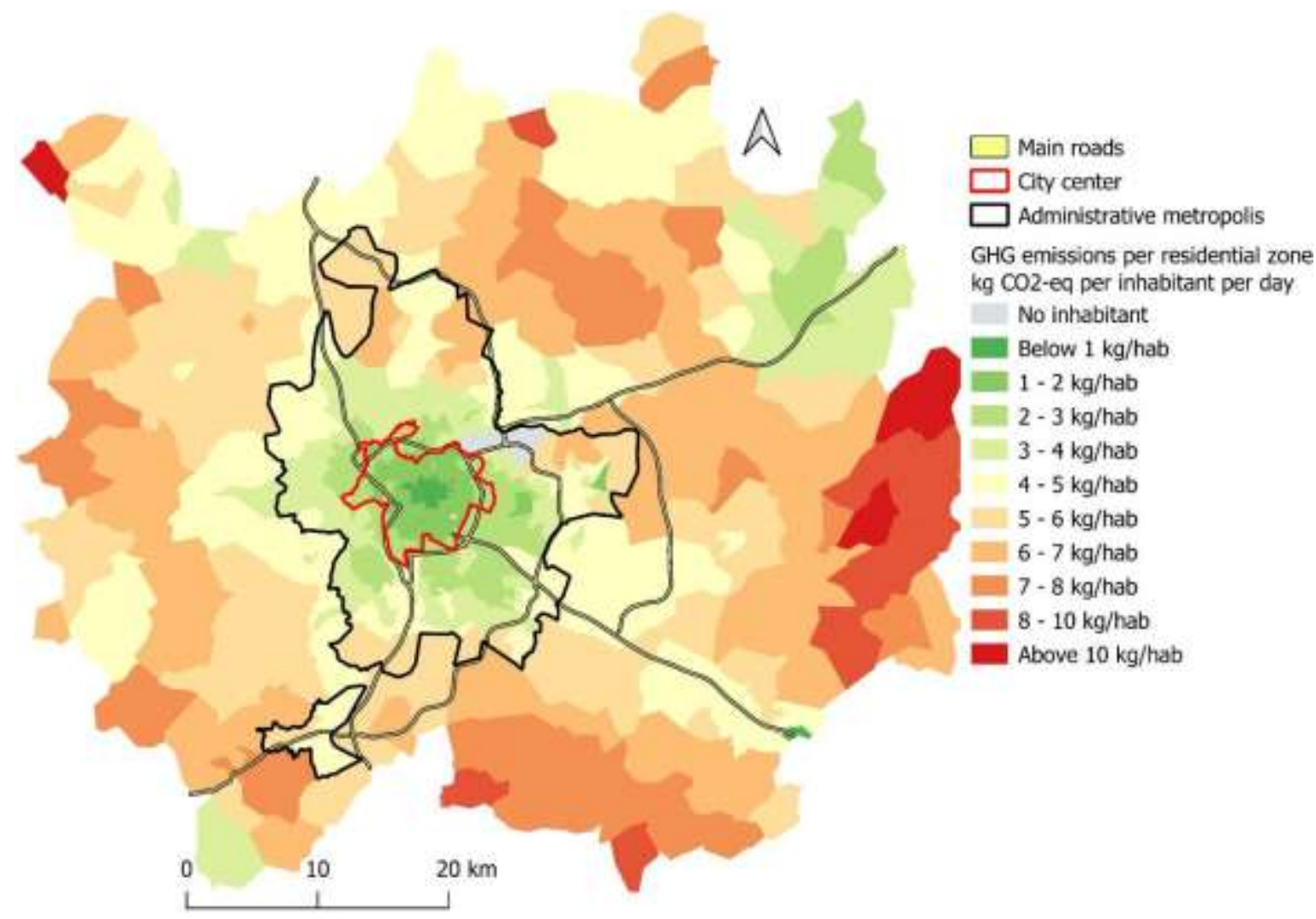

Fig. 5. GHG emissions per inhabitant per day in residential areas of Lyon urban area

The spatial resolution of Fig. 5, based on IRIS spatial units, reveals important spatial heterogeneity on the territory. Nonetheless, results interpretation should be made carefully at small scale in regards of potential statistical and modelling bias, e.g. edge effect or too small population. Through an urban form analysis, environmental impact's levels appear correlated with urban form indicators, such as population density, job accessibility, distance to centre or public transport accessibility.

\section{NOx exposure score}

The NOx exhaust-gas exposure score associated to daily mobility on the Lyon urban area is presented in Fig. 6. The exposure score estimation is based on a risk matrix with population density representing the likelihood and pollutant emissions density representing the impact severity, both based on quintiles. Due to population and road location, a major part of the Lyon urban area does not have any issue of local air quality and human health damage related to daily transport. By contrast, the major part of the city centre faces a human health issue related to air quality. The mean exposure level in Lyon city centre, calculated with population ponderation, is 4.02, compared to 2.35 for the whole urban area. Inside the administrative metropolis, a spatial differentiation is appreciable between the East and the West parts. East part is more affected due to the presence of more highways and activities compared to the West part composed with low-rise housing areas.

The mean exposure level of the urban area for the two simulated scenarios are displayed in Table 4. Through this methodology, the compact city scenario increases human health damage associated with daily transport operation emissions, even if total NOx emissions decrease. The densification of both population and mobility flows in the city centre is the main reason of this health issue degradation. On the other side, the electric vehicles scenario, by removing internal combustion vehicles, improves air quality and human health on the whole territory. 


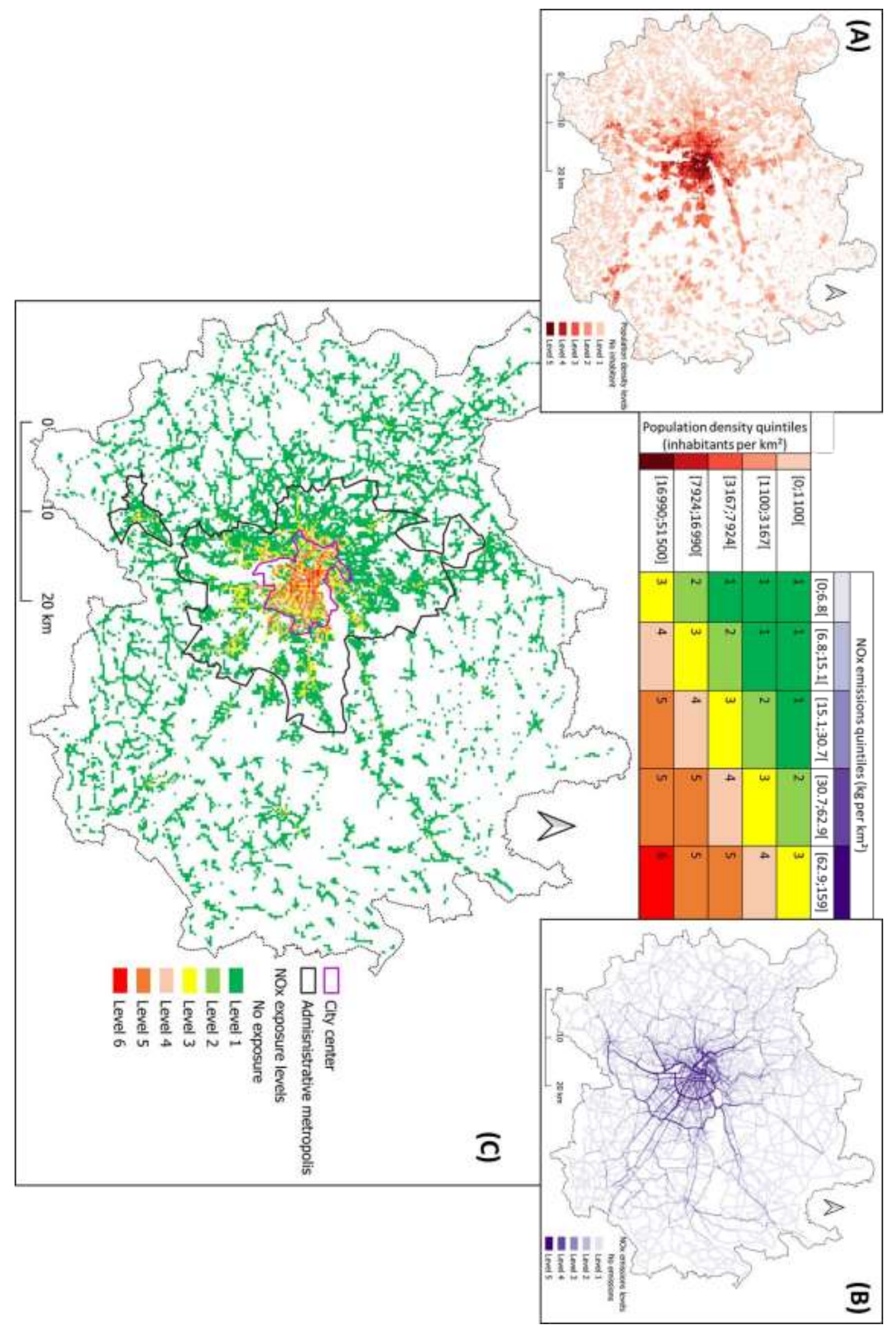

Fig. 6. Population density (A) and NOx exhaust-gas emissions density (B) related to daily mobility on the Lyon urban area; Population NOx exposure score (C) calculated at a 250mx250m square resolution. 


\section{Discussion}

4.1. Assessing Lyon urban mobility: the need of mobility data

The environmental assessment of urban area mobility with the LCA approach is unusual (e.g. Chester et al. 2010; Le Féon 2014; Nichols and Kockelman 2014) and often limited to its physical component (vehicles use). The present case study conducted on Lyon urban area presents a global GHG emissions per inhabitant per day of 3.2 $\mathrm{kg} \mathrm{CO}$-eq, which is include in the range estimated on four French other urban areas (2.4-3.4 kg CO -eq) with a survey approach (Le Féon 2014). Compared to similar LCA studies, the estimated GHG efficiency of the Lyon transport system (202 $\mathrm{g} \mathrm{CO}_{2}$-eq per pkm) is above others French cities (from 169 to $184 \mathrm{~g} \mathrm{CO}_{2}$-eq per pkm) but below American metropolis (from 220 to $290 \mathrm{~g} \mathrm{CO}_{2}$-eq per pkm) (Chester et al. 2010; Le Féon 2014). This case study also highlights the relevant contribution of vehicle production, fuel production and infrastructures phase in transport lifecycle.

The present case study also provides relevant information on environmental impacts of mobility for a territorial analysis, with off-site contribution (45\% of GHG emissions), spatial distribution of contributors (below $1 \mathrm{~kg} \mathrm{CO}_{2}$ eq per inhabitant per day in town centre to above $10 \mathrm{~kg}$ in peripheral areas), trip purposes analysis (56\% of GHG emissions are work related) or air pollutants exposure hotspots (mainly in city centre). Nonetheless, these analyses are the result of both important data collection, to build a LUTI model (transport networks, population and job distribution, mobility behaviours), to estimated vehicle fleets, and important data processing, to run iterative mobility model and to environmentally assess hundreds of thousands of transport links. Then the implementation of such spatial and territorial methods requires both data access and computing capability.

\subsection{Assessing local air pollution generated by daily mobility: the need of a territorial approach}

Nowadays, environmental impacts of transport systems are an important concern at global and local scale with significant contributions. However, mobility systems are pretty specific to local context in terms of behaviours and technologies. Then, this study makes a specific effort on foreground activities description through the application of an urban model and an emission model with local analyses of mobility behaviours and car fleets with surveys and databases. This description allows an accurate representation of on-site emissions and consumption, and a good appreciation of necessary background activities. The GIS information associated to foreground could be paired with spatialized characteristics factors to better assess local environmental impacts (Mutel and Hellweg 2009). Nonetheless, most spatialized LCIA methods evaluate regional impacts such as acidification, eutrophication, water scarcity rather than air pollution.

Human health arises as a major environmental concern in territorial assessment, especially in urban context, but few LCA characterization methods exist at local scale, especially coupled with GIS technologies. Humbert et al. proposed a characterization method for particulate matter intake based on emission release height and archetypes environment (indoor/urban/rural and remote location) (Humbert et al. 2011). Along the emission-to-damage framework, location of both emissions and population is an important information to improve the pollutant intake calculation. Atmospheric dispersion modelling could be added to adjust pollutant concentration with meteorological conditions and local topographic contexts. In addition to that, temporal variations on both the emission and the population location affect significantly the intake factor and then the CF. For example, transport emissions occur more intensively during peak hours and people move during the day depending on their activity schedules. Moreover, people are exposed to high pollutant concentration when travelling in public transport or in personal vehicles (Knibbs et al. 2011). The representation of these phenomena is a challenge for territorial assessment of local air pollutant impacts on human health and social models, such as urban models, by representing human flows along the day might bring a part of the solution.

\subsection{Assessing globally and locally: the need of multiscaled tools}

The goal and scope definition is a crucial step in LCA and it varies significantly with the scale of analysis, for example global scale with Strategic Environmental Assessment (SEA) or local scale with Environmental Impacts Assessment. In case of urban mobility, different layers of territorial entities and stakeholders are implied from the region to the neighbourhood. Each layer has different environmental concerns, different levers of actions and projects, leading to multiple goals and scopes to analyse them.

For daily mobility, small territories will lead to plenty of flow exchanges across the boundary with attribution choice among involved territories. By expanding territory boundaries to include almost all daily mobility flows of the inhabitants, attribution choices are avoided but sure expansion requires a lot of data. The territorial expansion also reduces the capability of such tool to answer specific issues arising at different levels, even by implementing 
disaggregated and spatialized analyses. On the contrary, specific mobility analysis conduct at specific territorial scale will lead to finer results but will miss potential multiscale synergies, such as walking policies at local scale emphasizes by central relocation promoted by regional policies. Then, the development of a multiscale mobility assessment tool requires important data and models to represent all interactions.

Finally, the development of a multiscale mobility tool, such as proposed in this study, faces similar issues than Consequential LCA, system expansion, modelling consequences, data needed or comprehensiveness. Then, the mobility assessment goal and territorial boundary definition should be coherent with the strategic or the projectoriented objective, in the same way as choosing between Attributional or Consequential LCA (Ekvall et al. 2016).

\subsection{Assessing various territorial mobility: the need of taking the multifunctionality of urban mobility into account}

Urban mobility is a complex system that can hardly be assessed, especially with the LCA approach. Indeed, the function definition is a tricky part because daily mobility performs distinctive functions. In this study, we proposed to analyse this multifunctionality by distinguishing between trip purposes, e.g. work, education, leisure, shopping. This approach facilitates the implementation of some diverse functions related to mobility but it nevertheless remains limited in regards to global territorial functions. Introduced as a support system for a territory in this study, the daily mobility should be related to the territory functions itself. These functions could be estimated with the land use functions framework defined by Perez-Soba et al. that identified them between economic, societal and environmental functions (Pérez-Soba et al. 2008). For urban territory, UN-Habitat also developed the City Prosperity Index that covers the three main functions (economic, social and environmental) with six different dimensions: productivity, infrastructure, quality of life, equity and social inclusion, environmental sustainability, and governance and legislation (Moreno and Murguía 2015). In 2016, the UN-Habitat database classified 295 cities around the world with this index. The development of a territorial functions evaluation method, with a scientific consensus, could allow comparative analysis of diverse territories and their associated mobility.

\section{Conclusion}

The recent development of Territorial (T-) and Spatialized (S-) LCA methodologies opens the LCA approach to new territorial objects such as daily urban mobility. Based on T-LCA and S-LCA recommendations, this paper proposes an assessment method for the daily mobility in a specific urban area, Lyon in France. To implement a LCA on daily mobility, urban planning sciences and environmental assessment were crossed with diverse tools: a LUTI model, mobility surveys, and an emissions model. This interdisciplinary coupling leads to an analytical framework able to assess environment burdens associated to daily mobility in regards of three different dimensions: (1) transport modes and technology analysis, (2) spatial, territorial and urban form analysis, and (3) trip purposes, behaviours and household characteristic analysis. This article focuses on the second dimension and it presents diverse spatial analysis that can be potentially helpful for territorial strategies (urban planning, incentive or tax, air quality improvement). By representing foreground activities accurately, with flow distribution, local vehicle fleets and speed conditions, the method improves the local representativeness and highlights a great variability inside the territory. Furthermore, a wide range of mobility scenarios can be explored, e.g. urban planning, technologies, behaviours.

In addition to proposing an original analytical framework for urban mobility, territorial and spatial challenges have been encountered. Firstly, local air pollutant impacts characterization in LCA methodologies appears insufficient in an urban context with high population density and high emissions concentration. The use of GIS information in the emission-to-damage chain seems promising to better represent intake factors and spatialized impacts. Secondly, functions related to urban mobility can be related to trip purposes but mobility functions are still strongly related to territorial functions. Then, the development and the standardization of a territorial functions evaluation method appears as a foundation for future Territorial LCA. Thirdly, urban mobility is a multiscale object and it could be assessed at local or at broader scale. The goal and boundary definition appears then as a crucial step in mobility assessment to choose proper scope and associated data and models. Finally, few LCA studies have been conducted on a complete urban transport system or on a mobility system, highlighting, among other things, the need to develop appropriate databases for transport technologies, especially for urban public transports. 


\section{References}

Aissani L (2008) Intégration des paramètres spatio-temporels et des risques d'accident à l'Analyse du Cycle de Vie : Application à la filière hydrogène énergie et à la filière essence. Phdthesis, Ecole Nationale Supérieure des Mines de Saint-Etienne

Albertí J, Roca M, Brodhag C, Fullana-i-Palmer P (2019) Allocation and system boundary in life cycle assessments of cities. Habitat International 83:41-54. https://doi.org/10.1016/j.habitatint.2018.11.003

André $\mathrm{M}$, Joumard R, Vidon R, et al (2006) Real-world European driving cycles, for measuring pollutant emissions from high- and low-powered cars. Atmospheric Environment 40:59445953. https://doi.org/10.1016/j.atmosenv.2005.12.057

André M, Pasquier A, Carteret M (2018) Experimental determination of the geographical variations in vehicle fleet composition and consequences for assessing low-emission zones. Transportation Research Part D: Transport and Environment 65:750-760. https://doi.org/10.1016/j.trd.2018.10.005

Azapagic A, Pettit C, Sinclair P (2007) A life cycle methodology for mapping the flows of pollutants in the urban environment. Clean Technologies and Environmental Policy 9:199-214. https://doi.org/10.1007/s10098-007-0092-9

Baitz M, Albrecht S, Brauner E, et al (2013) LCA's theory and practice: like ebony and ivory living in perfect harmony? Int J Life Cycle Assess 18:5-13. https://doi.org/10.1007/s11367-012-0476$\mathrm{X}$

Banister D (2008) The sustainable mobility paradigm. Transport Policy 15:73-80. https://doi.org/10.1016/j.tranpol.2007.10.005

Bauer C, Hofer J, Althaus H-J, et al (2015) The environmental performance of current and future passenger vehicles: Life cycle assessment based on a novel scenario analysis framework. Applied Energy 157:871-883. https://doi.org/10.1016/j.apenergy.2015.01.019

Belis CA, Karagulian F, Larsen BR, Hopke PK (2013) Critical review and meta-analysis of ambient particulate matter source apportionment using receptor models in Europe. Atmospheric Environment 69:94-108. https://doi.org/10.1016/j.atmosenv.2012.11.009

Boulay A-M, Bare J, Benini L, et al (2018) The WULCA consensus characterization model for water scarcity footprints: assessing impacts of water consumption based on available water remaining (AWARE). Int J Life Cycle Assess 23:368-378. https://doi.org/10.1007/s11367-017$1333-8$

Brown Weiss E (2011) The Evolution of International Environmental Law. Georgetown Law Faculty Publications and Other Works

Bulle C, Margni M, Patouillard L, et al (2019) IMPACT World+: a globally regionalized life cycle impact assessment method. Int J Life Cycle Assess 24:1653-1674. https://doi.org/10.1007/s11367019-01583-0

Cervero R, Kockelman K (1997) Travel demand and the 3Ds: Density, Diversity, and Design. Transport Research Part D: Transport and Environment 2:199-219 
Chester M (2008) Life-cycle environmental inventory of passenger transportation in the United States. Institute of Transportation Studies

Chester M, Horvath A (2009) Environmental assessment of passenger transportation should include infrastructure and supply chains. Environmental Research Letters 4:024008.

https://doi.org/10.1088/1748-9326/4/2/024008

Chester M, Horvath A, Madanat S (2010) Comparison of life-cycle energy and emissions footprints of passenger transportation in metropolitan regions. Atmospheric Environment 44:1071-1079. https://doi.org/10.1016/j.atmosenv.2009.12.012

Cortinovis J, Moreto F, Yahyaoui A, et al (2006) Élaboration d'un cadastre d'émissions interrégional pour la plate-forme de modélisation de prévisions cartographiques ESMERALDA Elaboration of an interregional emissions inventory for the modelling platform of cartographic previsions ESMERALDA. 20

de Bortoli A, Feraille A, Leurent F (2017) Life Cycle Assessment to support decision-making in transportation planning : a case of French Bus Rapid Transit. Washington DC, USA

Del Duce A, Gauch M, Althaus H-J (2014) Electric passenger car transport and passenger car life cycle inventories in ecoinvent version 3. The International Journal of Life Cycle Assessment. https://doi.org/10.1007/s11367-014-0792-4

Del Pero F, Delogu M, Pierini M, Bonaffini D (2015) Life Cycle Assessment of a heavy metro train. Journal of Cleaner Production 87:787-799. https://doi.org/10.1016/j.jclepro.2014.10.023

Dupuy G (1999) Les territoires de l'automobile. Economica Anthropos

EEA (2018) National emissions reported to the UNFCCC and to the EU Greenhouse Gas Monitoring Mechanism

EEA (2014) Noise in Europe 2014

Eichlseder H, Hausberger S, Rexeis M, et al (2009) Emission Factors from the Model PHEM for the HBEFA Version 3. Graz University of Technology

Ekvall T, Azapagic A, Finnveden G, et al (2016) Attributional and consequential LCA in the ILCD handbook. Int J Life Cycle Assess 21:293-296. https://doi.org/10.1007/s11367-015-1026-0

Enault C (2003) Vitesse, accessibilité et étalement urbain; analyse et application à l'aire urbaine dijonnaise. Université de Bourgogne

Eriksson M, Ahlgren S (2013) LCAs of petrol and diesel. SLU, S wedish University of Agricultural Science

European Commission/Joint Research Centre (2011) International reference life cycle data system (ILCD) handbook: general guide for life cycle assessment: provisions and action steps. Publications Office, Luxembourg

Ewing R, Cervero R (2001) Travel and the built environment: a synthesis. Transportation Research Record: Journal of the Transportation Research Board 87-114 
Ewing R, Cervero R (2010) Travel and the Built Environment: A Meta-Analysis. Journal of the American Planning Association 76:265-294. https://doi.org/10.1080/01944361003766766

Finnveden G, Hauschild MZ, Ekvall T, et al (2009) Recent developments in Life Cycle Assessment. Journal of Environmental Management 91:1-21. https://doi.org/10.1016/j.jenvman.2009.06.018

François C (2019) Évaluation environnementale stratégique de la mobilité quotidienne des personnes d'une aire urbaine : couplage entre Modèle Transport-Urbanisme et Analyse de Cycle de Vie. PhD Thesis, Lyon

François C, Gondran N, Nicolas J-P, Parsons D (2017) Environmental assessment of urban mobility: Combining life cycle assessment with land-use and transport interaction modellingApplication to Lyon (France). Ecological Indicators 72:597-604. https://doi.org/10.1016/j.ecolind.2016.07.014

García-Pérez S, Sierra-Pérez J, Boschmonart-Rives J (2018) Environmental assessment at the urban level combining LCA-GIS methodologies: A case study of energy retrofits in the Barcelona metropolitan area. Building and Environment 134:191-204. https://doi.org/10.1016/j.buildenv.2018.01.041

Goedkoop M, Heijungs R, Huijbregts M, et al (2009) ReCiPe 2008. A life cycle impact assessment method which comprises harmonised category indicators at the midpoint and the endpoint level 1:

Handy S (1996) Methodologies for exploring the link between urban form and travel behavior. Transport Research Part D: Transport and Environment 1:151-165

Hellmuth T, Classen T, Kim R, Kephalopoulos S (2012) Methodological guidance for estimating the burden of disease from environmental noise. World Health Organization

Hellweg S, Mila i Canals L (2014) Emerging approaches, challenges and opportunities in life cycle assessment. Science 344:1109-1113. https://doi.org/10.1126/science.1248361

Héran F, Ravalet EPJ (2008) La consommation d'espace-temps des divers modes de déplacement en milieu urbain, Application au cas de l'île de France. PREDIT

Hill J (2013) Life Cycle Analysis of Biofuels. In: Encyclopedia of Biodiversity (Second Edition). Academic Press, Waltham, pp 627-630

Hischier R, Weidema B, Althaus H-J, et al (2010) Implementation of Life Cycle Impact Assessment Methods. Ecolnvent

Hoffman AV, Felkner J (2002) The Historical Origins and Causes of Urban Decentralization in the United States. Joint Center for Housing Studies, Graduate School of Design [and] John F. Kennedy School of Government, Harvard University

Huijbregts MAJ, Schöpp W, Verkuijlen E, et al (2000) Spatially Explicit Characterization of Acidifying and Eutrophying Air Pollution in Life-Cycle Assessment. Journal of Industrial Ecology 4:75-92. https://doi.org/10.1162/108819800300106393 
Humbert S, Marshall JD, Shaked S, et al (2011) Intake Fraction for Particulate Matter: Recommendations for Life Cycle Impact Assessment. Environ Sci Technol 45:4808-4816. https://doi.org/10.1021/es103563z

Hunt JD, Kriger DS, Miller EJ (2005) Current operational urban land-use-transport modelling frameworks: A review. Transport Reviews 25:329-376. https://doi.org/10.1080/0144164052000336470

ICCT (2017) European vehicle market statistics: Pocketbook 2016/2017. The International Council on Clean Transportation

IEA (2019) World Energy Balances 2019

Ivanova D, Vita G, Steen-Olsen K, et al (2017) Mapping the carbon footprint of EU regions. Environ Res Lett 12:054013. https://doi.org/10.1088/1748-9326/aa6da9

Jolliet O, Saadé-Sbeith M, Shaked S, et al (2016) Environmental life cycle assessment. CRC Press, Taylor \& Francis Group, Boca Raton

Jones J (2016) Spatial bias in LUTI models. Université catholique de Louvain

Karlsson CSJ, Miliutenko S, Björklund A, et al (2017) Life cycle assessment in road infrastructure planning using spatial geological data. The International Journal of Life Cycle Assessment 22:1302-1317. https://doi.org/10.1007/s11367-016-1241-3

Kaufmann V, Bergman MM, Joye D (2004) Motility: mobility as capital. International journal of urban and regional research $28: 745-756$

Kenworthy JR (2003) Transport energy use and greenhouse gases in urban passenger transport systems: a study of 84 global cities

Knibbs LD, Cole-Hunter T, Morawska L (2011) A review of commuter exposure to ultrafine particles and its health effects. Atmospheric Environment 45:2611-2622. https://doi.org/10.1016/j.atmosenv.2011.02.065

Krewitt W, Trukenmüller A, Bachmann TM, Heck T (2001) Country-specific damage factors for air pollutants. Int J LCA 6:199. https://doi.org/10.1007/BF02979375

Kumar P, Morawska L, Birmili W, et al (2014) Ultrafine particles in cities. Environment International 66:1-10. https://doi.org/10.1016/j.envint.2014.01.013

Laurent $F$ (2015) Optimisation fonctionnelle et spatiale de scénarios de méthanisation centralisée selon une approche systémique territoriale couplée à l'analyse du cycle de vie. Université de Rennes 1

Le Féon S (2014) Evaluation environnementale des besoins de mobilité des grandes aires urbaines en France-Approche par Analyse de Cycle de Vie. Saint-Etienne, EMSE

Le Féon S, Gondran N, Laforest V, Le Boulch D (2012) Global warming impact assessment of urban mobility using motivation trip perspective - a case study of Saint-Etienne, France. International Journal of Environmental Science and Engineering Research Vol 3(3):pp.86-101 
Liu KF-R, Hung M-J, Yeh P-C, Kuo J-Y (2014) GIS-Based Regionalization of LCA. GEP 02:1-8. https://doi.org/10.4236/gep.2014.22001

Loiseau E, Aissani L, Le Féon S, et al (2018) Territorial Life Cycle Assessment (LCA): What exactly is it about? A proposal towards using a common terminology and a research agenda. Journal of Cleaner Production 176:474-485. https://doi.org/10.1016/j.jclepro.2017.12.169

Loiseau E, Roux P, Junqua G, et al (2013) Adapting the LCA framework to environmental assessment in land planning. Int J Life Cycle Assess 18:1533-1548. https://doi.org/10.1007/s11367-0130588-y

Luz R, Hausberger S (2010) User Guide for the Model PHEM, Handbuch. Graz

Ma H, Balthasar F, Tait N, et al (2012) A new comparison between the life cycle greenhouse gas emissions of battery electric vehicles and internal combustion vehicles. Energy Policy 44:160-173. https://doi.org/10.1016/j.enpol.2012.01.034

Marshall S, Banister D (eds) (2007) Land use and transport: European research towards integrated policies. Elsevier, Amsterdam London

Menten F, Chèze B, Patouillard L, Bouvart F (2013) A review of LCA greenhouse gas emissions results for advanced biofuels: The use of meta-regression analysis. Renewable and Sustainable Energy Reviews 26:108-134. https://doi.org/10.1016/j.rser.2013.04.021

Milakis D, Cervero R, Van Wee B (2015) Stay local or go regional? Urban form effects on vehicle use at different spatial scales: A theoretical concept and its application to the San Francisco Bay Area. Journal of Transport and Land Use 8:. https://doi.org/10.5198/jtlu.2015.557

Minx J, Baiocchi G, Wiedmann T, et al (2013) Carbon footprints of cities and other human settlements in the UK. Environ Res Lett 8:035039. https://doi.org/10.1088/17489326/8/3/035039

Mirabella N, Allacker K, Sala S (2018) Current trends and limitations of life cycle assessment applied to the urban scale: critical analysis and review of selected literature. The International Journal of Life Cycle Assessment. https://doi.org/10.1007/s11367-018-1467-3

Moine A (2006) Le territoire comme un système complexe : un concept opératoire pour l'aménagement et la géographie. LEspace geographique Tome 35:115-132

Moreno EL, Murguía RO (2015) The City Prosperity Initiative: 2015 Global City Report. UN-Habitat

Mutel CL, Hellweg S (2009) Regionalized Life Cycle Assessment: Computational Methodology and Application to Inventory Databases. Environ Sci Technol 43:5797-5803. https://doi.org/10.1021/es803002j

Naess P (2012) Urban form and travel behavior: experience from a Nordic context. Journal of Transport and Land Use 5:21-45. https://doi.org/10.5198/jtlu.v5i2.314

Newman PWG, Kenworthy JR (1999) Sustainability and Cities: Overcoming Automobile Dependence. Island Press, Washington D.C., USA 
Nichols BG, Kockelman KM (2014) Life-cycle energy implications of different residential settings: Recognizing buildings, travel, and public infrastructure. Energy Policy 68:232-242. https://doi.org/10.1016/j.enpol.2013.12.062

Nicolas J-P, Bonnel P, Cabrera J, et al (2009) SImuler les MoBilités pour une Agglomération Durable. Laboratoire d'Économie des Transports

Nitschelm L, Aubin J, Corson MS, et al (2016) Spatial differentiation in Life Cycle Assessment LCA applied to an agricultural territory: current practices and method development. Journal of Cleaner Production 112:2472-2484. https://doi.org/10.1016/j.jclepro.2015.09.138

Ntziachristos L, Samaras Z, Kouridis C, et al (2014) COPERT Guidebook 2014 : Exhaust emissions from road transport. Guidebook

Ntziachristos L, Samaras Z, Kouridis C, et al (2016) EMEP/EEA air pollutant emission inventory guidebook 2016 - Passenger cars, light commercial trucks, heavy-duty vehicles including buses and motor cycles. 153

O'Keeffe S, Majer S, Bezama A, Thrän D (2016) When considering no man is an island-assessing bioenergy systems in a regional and LCA context: a review. Int J Life Cycle Assess 21:885-902. https://doi.org/10.1007/s11367-016-1057-1

Ostrom E (2009) A Polycentric Approach for Coping with Climate Change. World Bank

Patouillard L, Collet P, Tirado-Seco P, et al (2016) Prioritize regional data collection based on uncertainty analysis to enhance the quality of LCA results. LCA XVI undefined-undefined

Pérez-Soba M, Petit S, Jones L, et al (2008) Land use functions - a multifunctionality approach to assess the impact of land use changes on land use sustainability. In: Helming K, Pérez-Soba M, Tabbush P (eds) Sustainability Impact Assessment of Land Use Changes. Springer Berlin Heidelberg, Berlin, Heidelberg, pp 375-404

Potting J, Hauschild M (1997) Part II: spatial differentiation in life-cycle assessment via the sitedependent characterisation of environmental impact from emissions. The International Journal of Life Cycle Assessment 2:209-216. https://doi.org/10.1007/BF02978417

Potting J, Schöpp W, Blok K, Hauschild M (1998) Site-Dependent Life-Cycle Impact Assessment of Acidification. Journal of Industrial Ecology 2:63-87. https://doi.org/10.1162/jiec.1998.2.2.63

Querini F, Benetto E (2015) Combining Agent-Based Modeling and Life Cycle Assessment for the Evaluation of Mobility Policies. Environmental Science \& Technology 49:1744-1751. https://doi.org/10.1021/es5060868

Reed MS (2008) Stakeholder participation for environmental management: A literature review. Biological Conservation 141:2417-2431. https://doi.org/10.1016/j.biocon.2008.07.014

Saner D, Beretta C, Jäggi B, et al (2016) FoodPrints of households. Int J Life Cycle Assess 21:654-663. https://doi.org/10.1007/s11367-015-0924-5

Santos JM, Flintsch G, Ferreira A (2017) Environmental and economic assessment of pavement construction and management practices for enhancing pavement sustainability. Resources Conservation and Recycling 15-31 
Saujot M, de Lapparent M, Arnaud E, Prados E (2015) To make LUTI models operational tools for planning. Transport and Mobility Laboratory - Ecole Polytechnique Fédérale de Lausanne

Schafer A, Victor DG (2000) The future mobility of the world population. Transportation Research Part A: Policy and Practice 34:171-205. https://doi.org/10.1016/S0965-8564(98)00071-8

Schwanen T, Dijst M, Dieleman F (2004) Policies for urban form and their impact on travel: the Netherlands experience. Urban Studies 41:579-603. https://doi.org/10.1080/0042098042000178690

Servant L (1996) L'Automobile dans la ville: l'envers d'un indéniable succès / The automobile in the city: the flip side of a genuine success story. Cahier de l'IAURIF 7-21

Shaheen SA, Chan ND, Gaynor T (2016) Casual carpooling in the San Francisco Bay Area: Understanding user characteristics, behaviors, and motivations. Transport Policy 51:165173. https://doi.org/10.1016/j.tranpol.2016.01.003

Smit R (2006) An examination of congestion in road traffic emission models and their application to urban road networks. 22

Stead D, Marshall S (2001) The relationships between urban form and travel patterns. An international review and evaluation. European Journal of Transport and Infrastructure Research 1:113-141

Tagliaferri C, Evangelisti S, Acconcia F, et al (2016) Life cycle assessment of future electric and hybrid vehicles: A cradle-to-grave systems engineering approach. Chemical Engineering Research and Design 112:298-309. https://doi.org/10.1016/j.cherd.2016.07.003

UNCED (1992) Agenda 21

Wegener M, Fürst F (2004) Land-Use Transport Interaction: State of the Art. SSRN Electronic Journal. https://doi.org/10.2139/ssrn.1434678

Wernet G, Bauer C, Steubing B, et al (2016) The ecoinvent database version 3 (part I): overview and methodology. Int J Life Cycle Assess 21:1218-1230. https://doi.org/10.1007/s11367-0161087-8

Wiel M (1999) Mobilité, système d'interactions sociales et dynamiques territoriales. Espace, populations, sociétés 17:187-194. https://doi.org/10.3406/espos.1999.1884

Wilson A (2010) The general urban model: Retrospect and prospect: The general urban model: Retrospect and prospect. Papers in Regional Science 89:27-42.

https://doi.org/10.1111/j.1435-5957.2010.00282.x

Zahavi Y, Ryan JM (1980) Stability of Travel Components over Time. Transportation Research Record 750:19-26 


\section{Supplementary information}

Synthetic personal vehicles fleets description:

\begin{tabular}{|c|c|c|c|c|c|c|c|c|c|c|c|}
\hline \multirow{3}{*}{\multicolumn{2}{|c|}{ Income class: }} & \multicolumn{3}{|c|}{ Urban centre } & \multicolumn{3}{|c|}{ Inner-suburbs } & \multicolumn{3}{|c|}{ Outer-suburbs } & \multirow{2}{*}{$\begin{array}{l}\text { Fleet } \\
\text { mean }\end{array}$} \\
\hline & & low & median & high & low & median & high & low & medium & high & \\
\hline & & & & & & & & & & & \\
\hline \multirow{10}{*}{ 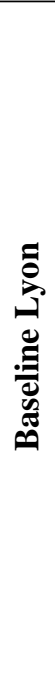 } & Petrol & $75 \%$ & $63 \%$ & $70 \%$ & $72 \%$ & $68 \%$ & $71 \%$ & $71 \%$ & $74 \%$ & $74 \%$ & $70 \%$ \\
\hline & Electric & $25 \%$ & $33 \%$ & $28 \%$ & $28 \%$ & $29 \%$ & $28 \%$ & $29 \%$ & $25 \%$ & $23 \%$ & $28 \%$ \\
\hline & Hybrid & $0,0 \%$ & $0,4 \%$ & $1,1 \%$ & $0,0 \%$ & $0,2 \%$ & $0,1 \%$ & $0,0 \%$ & $0,1 \%$ & $0,1 \%$ & $0,3 \%$ \\
\hline & LPG & $0,0 \%$ & $1,4 \%$ & $0,2 \%$ & $0,0 \%$ & $1,4 \%$ & $0,6 \%$ & $0,0 \%$ & $0,1 \%$ & $0,7 \%$ & $0,8 \%$ \\
\hline & Age (yr) & $0,0 \%$ & $2,0 \%$ & $0,5 \%$ & $0,0 \%$ & $1,2 \%$ & $0,1 \%$ & $0,0 \%$ & $1,3 \%$ & $1,8 \%$ & $1,1 \%$ \\
\hline & GHG & 11,7 & 7,5 & 5,5 & 10,0 & 7,6 & 5,1 & 9,4 & 7,3 & 6,5 & 7,0 \\
\hline & ( vkm) & 296 & 302 & 304 & 296 & 299 & 301 & 298 & 297 & 296 & 298 \\
\hline & Car & & & & & & & & & & \\
\hline & $\begin{array}{l}\text { occupancy } \\
\text { GHG }\end{array}$ & 1.31 & 1.23 & 1.22 & 1.32 & 1.24 & 1.22 & 1.36 & 1.28 & 1.26 & 1.26 \\
\hline & / pkm ) & 226 & 246 & 249 & 224 & 241 & 247 & 219 & 232 & 235 & 237 \\
\hline \multirow{5}{*}{ 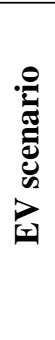 } & Diesel & & & & & & & & & & \\
\hline & Petrol & $65 \%$ & $48 \%$ & $40 \%$ & $61 \%$ & $51 \%$ & $41 \%$ & $61 \%$ & $55 \%$ & $48 \%$ & $52 \%$ \\
\hline & Electric & $22 \%$ & $26 \%$ & $18 \%$ & $24 \%$ & $23 \%$ & $18 \%$ & $22 \%$ & $21 \%$ & $17 \%$ & $22 \%$ \\
\hline & GHG & $13 \%$ & $26 \%$ & $42 \%$ & $15 \%$ & $25 \%$ & $41 \%$ & $17 \%$ & $24 \%$ & $34 \%$ & $26 \%$ \\
\hline & / pkm ) & 211 & 213 & 190 & 206 & 208 & 197 & 199 & 202 & 190 & 202 \\
\hline
\end{tabular}

Public transports sharing, occupancy and mean GHG emissions in Lyon urban area:

\begin{tabular}{lcccccccc}
\hline & \multicolumn{4}{c}{ GHC emissions per vkm $(\mathrm{kg}$ CO2-eq) } & \multicolumn{2}{c}{$\begin{array}{c}\text { Vehicle } \\
\text { occupancy }\end{array}$} & $\begin{array}{c}\text { GHG emissions } \\
\text { per pkm }\end{array}$ \\
& $\begin{array}{c}\text { \% of } \\
\text { vkm }\end{array}$ & $\begin{array}{c}\text { Veh. } \\
\text { operation }\end{array}$ & $\begin{array}{c}\text { Fuel } \\
\text { prod. }\end{array}$ & $\begin{array}{c}\text { Vehicle } \\
\text { prod. }\end{array}$ & Infrastr. & Total & (nb. pax) & (g CO2-eq) \\
\hline Bus & $64 \%$ & 1,04 & 0,26 & 0,11 & 0,22 & 1,62 & 15,1 & 107 \\
Subway & $11 \%$ & 0,00 & 0,82 & 0,53 & 2,25 & 3,60 & 33,9 & 106 \\
Tramway & $7 \%$ & 0,00 & 0,82 & 0,32 & 2,07 & 3,21 & 25 & 128 \\
Train & $17 \%$ & 0,00 & 0,81 & 0,18 & 1,71 & 2,70 & 30,7 & 88 \\
\hline $\begin{array}{l}\text { Lyon public } \\
\text { transports }\end{array}$ & 0,67 & 0,54 & 0,18 & 0,83 & 2,22 & 20,6 & 108 \\
\hline
\end{tabular}

